4.11

doi: 10.15789/2220-7619-2018-4-4.11

INTERNATIONAL COLLABORATIVE PROJECT ON TICK-BORNE ENCEPHALITIS IN THE BARENTS REGION

O. Freylikhman ${ }^{1}$, Yu. Panferova ${ }^{1}$, N. Tokarevich ${ }^{1}$,

K.M. Paulsen ${ }^{6}$, A. Soleng ${ }^{6}$, K.S. Edgar ${ }^{6}$,

V. Kjelland ${ }^{7}$, S. Stuen ${ }^{8}$, A. Jenkins ${ }^{9}$,

N. Stoyanova ${ }^{1}$, O. Blinova ${ }^{1}$, M. Voloshuk ${ }^{2}$,

O. Sokolova ${ }^{2}$, M. Gorbatova ${ }^{3}$, L. Bubnova ${ }^{10}$,

M. Komissarova ${ }^{10}$, I. Chkhindzheriya ${ }^{11}$,

A. Shapar ${ }^{12}$, A. Madoyan ${ }^{13}$, A. Zabolotnov' ${ }^{14}$,

E. Kalinina ${ }^{15}$, A. Stankevich ${ }^{16}$, A. Tronin ${ }^{4}$,

L. Karan ${ }^{5}$, A.K. Andreassen ${ }^{6}$

${ }^{1}$ St. Petersburg Pasteur Institute, St. Petersburg, Russia;

${ }^{2}$ Directorate of Rospotrebnadzor in Arkhangelsk Region,

Arkhangelsk, Russia; ${ }^{3}$ Center for Hygiene and Epidemiology

for Arkhangelsk Region, Arkhangelsk, Russia;

${ }^{4}$ Scientific Research Center for Ecological Safety, Russian

Academy of Sciences, St.Petersburg, Russia;

5 “InterLabService”, Moscow, Russia; ${ }^{6}$ Norwegian Institute of Public Health, Oslo, Norway; ${ }^{7}$ University of Agder,

Kristiansand, Vest-Agder, Norway; ${ }^{8}$ Norwegian University

of Life Sciences, Oslo, Norway; ${ }^{9}$ Institute for Nature,

Health and Environment, University College of Southeast

Norway, Oslo, Norway; ${ }^{10}$ Centre of Hygiene and Epidemiology

in the Republic of Karelia, Petrozavodsk, Russia;

${ }^{11}$ Directorate of Rospotrebnadzor in St. Petersburg,

St. Petersburg, Russia; ${ }^{12}$ Centre of Hygiene and

Epidemiology in St. Petersburg, St. Petersburg, Russia,

${ }^{13}$ Directorate of Rospotrebnadzor in Leningrad Region,

St. Petersburg, Russia; ${ }^{14}$ Centre of Hygiene and Epidemiology

in Leningrad Region, St. Petersburg, Russia; ${ }^{15}$ Directorate

of Rospotrebnadzor in Pskov Region, Pskov, Russia;

${ }^{16}$ Centre of Hygiene and Epidemiology in Pskov Region,

Pskov, Russia

An international joint project on the surveillance of tick-borne encephalitis (TBE) in the Barents region was implemented in Norway and in NW Russia.

The project objective was to analyze hard ticks in endemic, non-endemic and borderline endemic areas within the Barents region, to verify the range of Ixodidae occurrence, and to define the northern limit of tick-borne encephalitis virus (TBEV) distribution.

Ticks were flagged in 2014-2015 (May-June) at several sites in Norway: from $58^{\circ} \mathrm{N}$ (Mandal) to $65^{\circ} \mathrm{N}$ (Brønnøysund), and in Russia: from $57^{\circ} \mathrm{N}$ (Pskov) to $64^{\circ} \mathrm{N}$ (Zachapino, the Arkhangelsk Oblast). TBEV was detected by real-time PCR.

Ticks collected in Russia were mostly I. perculcatus, while all those in Norway were I. ricinus. Each tick was studied individually. TBEV detected in Russian samples belonged to Siberian genotype, while in Norwegian samples it was only European genotype. TBEV prevalence in ticks collected in Russia was: $0.5 \%$ in St. Petersburg and in the Leningrad Oblast, 1.3\% in the Pskov Oblast, 3.9\% in the Arkhangelsk Region, $4.4 \%$ in Karelia.

In Russia fifty years ago scanty TBE cases were reported only in the south of the area under study, but now TBE is registered in most of districts, including the north of Arkhangelsk Oblast. In Norway TBE cases in humans are currently reported only in the south, however, TBEV is detected in questing ticks up to Brønnøy county. This northward shift of TBE in the northern Europe is a serious challenge to public health care.
4.12

doi: 10.15789/2220-7619-2018-4-4.12

IS THERE A TRANSOVARIAL TRANSMISSION OF TAIGA TICK (IXODES PERSULCATUS Sch.) AND THE SHEEP TICK (IXODES RICINUS (L.)) THE CAUSATIVE AGENT OF IXODID TICK-BORNE BORRELIOSIS (BORRELIA BURGDORFERI S.I.)?

L.A. Grigoryeva' ${ }^{1}$ O.A. Miteva ${ }^{1}$, V.A. Myasnikov ${ }^{2}$, A.S. Gogolevsky ${ }^{2}$

${ }^{1}$ Zoological Institute of RAS, St. Petersburg, Russia $;{ }^{2}$ Research Experimental Institute of Military Medicine, St. Petersburg, Russia

Ixodes ricinus (L.) and Ixodes persulcatus Sch. (Acari: Ixodidae) - the main vectors of pathogens of tick-borne borreliosis of humans. Transovarial transmission of the pathogen from the infected female to the eggs can serve as a mechanism for the vertical transmission of Borrelia to new generations of ticks in nature. At present, this issue has not been finally resolved, although it is generally believed that the transovarial transmission of Borrelia has no appreciable significance in maintaining their circulation and forming the level of infestation of adult ticks of the following generations (Korenberg et al., 2013).

Collected in May 2018 in natural biotopes of the Leningrad Region, adult females and males of taiga and sheep ticks were planted on rabbits for feeding. Of the 20 females of each species, 15 females of I. persulcatus and 17 females of I. ricinus were feed in June. In July, 15 females of I. persulcatus and 13 females of I. ricinus laid eggs. Determination of the presence of $B$. burgdorferi sensu lato complex DNA in females and samples of their clutches was carried out using the PCR method with hybridizationfluorescent detection in real time using a commercial set of AmpliSens (Interlabservis, Russia).The amplification was performed on a Quantcudio 3 thermocycler (Applied Biosystems, USA) A positive response to B. burgdorferi was found in $5(38.5 \%)$ of I. ricinus females and 7 (46.7\%) of $I$. persulcatus females. No laying eggs positive reaction did not. According to our results, transvarial transmission of $B$. burgdorferi sensu lato in I. persulcatus and I. ricinus is absent.

\subsection{3}

doi: 10.15789/2220-7619-2018-4-4.13

\section{FEATURES OF BACILLUS ANTHRACIS IDENTIFICATION BY MALDI-TOF MS}

E.A. Koteneva, A.V. Kalinin, O.I. Tsygankova

Stavropol Plague Control Research Institute, Stavropol, Russia

Identification of $B$. anthracis is an important stage in laboratory diagnosis of anthrax, a dangerous infectious disease of humans and animals. The application of sensitive and rapid method of MALDI-TOF MS for this purpose is difficult owing to considerable homology of protein spectra of B. anthracis and closely related saprophytes of the genus Bacillus. It requires creation of databases of reference mass spectra of various representatives of the given genus and development of algorithms of their analysis.

The aim of the work was to develop a technical approach for reliable identification of $B$. anthracis with using MALDI-TOF MS.

We used 72 strains of saprophytes of the genus Bacillus, including strains belonging to the group Bacillus cereus, and 37 strains of the causative agent of anthrax, differing in their biological properties. To prevent spore formation and eliminate signals of spore proteins from spectra under study, cultures were reinoculated twice. Samples were prepared by lysis of 18-hour cultures and extraction of acid-soluble proteins by $80 \%$ TFA with the subsequent ultra-micro-centrifuge filtration. Collection of spectra 